Publisher homepage: www.universepg.com, ISSN: 2663-7804 (Online) \& 2663-7790 (Print) https://doi.org/10.34104/ajeit.020.066076

Australian Journal of Engineering and Innovative Technology

Journal homepage: www.universepg.com/journal/ajeit

\title{
Exploring the Effect of Rainfall Variability and Water Extent in Tanguar Haor, Sunamganj
}

\section{Ripon Bagchi ${ }^{1}$, Md. Alim Miah ${ }^{2}$, Papri Hazra ${ }^{3}$, Robiul Hasan ${ }^{4}$, Himadree Shekhar Mondal $^{5}$, and Sujan Kumar Paul ${ }^{6}$}

${ }^{1}$ Dept. of Disaster Risk Management, Patuakhali Science and Technology University, Dumki, Patuakhali, Bangladesh; ${ }^{2}$ Dept. of Environmental Science and Engineering, Jatiya Kabi Kazi Nazrul Islam University, Trishal, Mymensingh, Bangladesh; ${ }^{3}$ Dept. of Environmental Science, Patuakhali Science and Technology University, Dumki, Patuakhali, Bangladesh; ${ }^{4}$ Centre for Disability in Development (CDD), Dhaka, Bangladesh; ${ }^{5}$ An Organization for Socio-Economic Development (AOSED), Khulna, Bangladesh; and ${ }^{6}$ Dept. of Chemistry, Govt. P.C. College, Bagerhat, Bangladesh.

*Correspondence: ribagchi@gmail.com

\begin{abstract}
Tanguar haor is located in the north-eastern region of Bangladesh and frequently experienced extreme events such as high rainfall that affect the haor basin area with flash floods on a regular basis. Tanguar haor is usually foreseen to severe disastrous conditions for the reason of changes in rainfall patterns and water extent. The study was conducted at Tanguar haor of Sunamganj district. This study mainly focuses on the year to year rainfall variability (2001-2018) and water extent (2002-2018) in the Tanguar haor area. The specific objective of the study was to explore the effect of rainfall variability and water extent in Tanguar haor. Information and data were collected mainly from secondary sources. Analysis of data and assess the ecological effect of changes in rainfall patterns and water extent were the main activities of the study along with others. The findings of the study were changeability in rainfall patterns and water extent frequently caused a flash flood in pre-monsoon and monsoon season in the Tanguar haor area. Flash flood causes a vast amount of financial loss for the living people of the Tanguar haor that makes them more vulnerable to live well. The result of this study may help to gather new knowledge on the consequences of rainfall variability and water extent in the haor basin area. It may add the significance for the management of flash flood and severe stress in haor basin area.
\end{abstract}

Keywords: Tanguar haor, Rainfall variability, Water extent, Flash flood, Analysis, Impact, and Flash flood.

\section{INTRODUCTION:}

Bangladesh with an area of 147,570 sq. $\mathrm{km}$ that lies between $20^{\circ} 34^{\prime}-26^{\circ} 38^{\prime} \mathrm{N}$, and $88^{\circ} 01^{\prime}-92^{\circ} 41^{\prime} \mathrm{E}$ (Rashid, 1991). Bangladesh is widely recognized as one of the most climate vulnerable countries in the world. Haor basin area situated in north-eastern part usually characterizes with large to medium flood plain depressions (Sara et al., 2013). Hydroecological features of haor basin area are flood plain and marshy lands covered approximately 1.99 million hectares of area and accommodating approximately 19.37 million of people (BHWDB, 2012). Haor areas are generally featured as bowlshaped large tectonic depressions and receive large amount of surface runoff water by rivers, khals and become very extensive water body in the monsoon but dries up mostly in the post-monsoon period (Bevanger et al., 2001; and IUCN, 2002). Now-adays Bangladesh predicted as most vulnerable country due to climate change (rainfall and water extent) particularly in haor basin area on account of geographic location, feature of flood plains, 
growing density of population, extreme poverty and very high dependency on the natural resources (Rahaman et al., 2014). Covering 9,727 hectares, Tanguar haor in north-east part of Bangladesh, adjacent to the Indian border, is part of wetland of the Surma-Kushiyara rivers basins (BHWDB, 2012).

Nowadays the variability of climatic parameter has become a challenging issue. Tanguar haor (ecosystem, livelihoods, and living people) are especially sensitive to the different natural disasters including flash flood, drought and storm surges (Munasinghe, 2000). Rainfall as well as temperature is two major climatic variables that structured the socioecological system (Klain, 1998). Any change in rainfall pattern and temperature cycle and water extent as a result of climate change caused flash flood in Tanguar haor (Elahi, 1988). Climatic feature of Tanguar haor are subtropical monsoon nature with three dominating seasons likely summer, monsoon and winter. Summer is from April to June and temperature ranges from 30.9 to 33.4 degree celsius. Winter is from October to February and temperature ranges from 8.5 to 16.6 degree celsius (Rahaman et al., 2014). Average annual rainfall is $8000 \mathrm{~mm}$ in northern part of Sunamganj. Within Sylhet region out of total annual rainfall $65-69 \%$ rainfall occurs in summer. The spring experiences with $21-23 \%$ of annual rainfall and the autumn experiences with 6$8 \%$ of annual rainfall (Rahaman et al., 2014). High rainfall during pre-monsoon season causes flash flood in haor area (Munasinghe, 2000).

Tanguar haor in Sunamganj district of Sylhet division experiences high variability in rainfall and water extent on a regular basis. This causes flash flood event more severe in the Tanguar haor. During low water level the haor area experiences drought condition but very less in average. Due to climate change, high population density, environmental degradation causes several natural disasters in haor area. But flash flood event are more frequent in this area rather than others. There has been relatively little scientific research characterizing the variability in rainfall and water extent as outcomes of flood hazards and similarly, little social science research targeting how vulnerable populations perceive to flood risks through mitigation strategies. Rainfall is one the major determinants of flood severity in Bangladesh especially in the haor basin area. Recent floods have turned into catastrophe due to huge water flow from the upstream point and regional rainfall acted as an auxiliary factor which accelerates the situation to be worst. During the month of November to February the Tanguar haor area experiences low rainfall and water extent, March to May experiences medium or average rainfall and water extent and in the month of April to September the experiences high rainfall variability and water extent. Due to heavy rainfall the study area usually experiences flood in monsoon season but, sometimes during pre-monsoon season heavy rainfall and streams from mountains area raises the water level of bounded rivers that flows to the haor basins and causes flash flood in the Tanguar haor of Sunamganj. Northern parts and the eastern parts of Bangladesh usually affects by the extent of flash floods. A flash flood is considered with the high rises of water level of rivers and subsequent overbank discharge with very high velocity due to high rainfall. In Tanguar hoar area, flash flood arises after math of heavy rainfall, rises of water level in the Surma River and heavy inundation in the adjacent hills and mountains. These floods often destroy the standing crops at the ripening stage and cause severe damages to the physical infrastructures along haor basin area (Saju et al., 2020).

Considering all of these issues this study focuses on the variability in rainfall pattern and water extent in Tanguar haor area. The specific objectives of the study were as follows: (i) to analyze major climate change parameters (rainfall, water level); (ii) to find out the effect of rainfall variability and water extent in the study area; (iii) to follow up some measures for the management of flash flood in Tanguar haor area. This study may help to reveal the actual scenario and to take practical actions for the management of flash flood and ecological balance in the haor basin area.

\section{MATERIALS AND METHODS:}

Selection of the Study Area - The study was conducted at Dharmapasha and Tahirpur upazilas of Sunamganj District in Bangladesh. Sunamganj is situated in the Sylhet division with the Sylhet district adjacent to east, Habiganj district in south and Netrokona district in west (Siddiqi, 2012). The Surma, Kushiyara and Danuka river go through the district where as the Ratna River crossed the Sunamganj district. Sunamganj has a maximum of 33.2 degree celsius and a minimum 13.6 degree celsius 
annual average temperature with annual rainfall of $3334 \mathrm{~mm}$ (Ashfaq, 2012). There are many haor and beel (wetlands ecosystems) in Sunamganj. Tanguar haor in Sunamganj district has particular wetland ecosystem of countrywide importance and already came into international focus with the international recognition as Ramsar sites and world heritage by UNESCO. Geographical position of Tanguar haor is at $25^{\circ} 06^{\prime}$ to $25^{\circ} 11^{\prime} \mathrm{N}$ and $91^{\circ} 01^{\prime}$ to $91^{\circ} 06^{\prime} \mathrm{E}$. The area of Tanguar haor includes 46 villages within the haor basin is approximately $100 \mathrm{~km}^{2}$ of which 2,802.36 $\mathrm{ha}^{2}$ is wetland (Asfhaq, 2012). It is the source of livelihood for more than 40,000 people (IUCN, 2007).

Study Design - Every stage for the formulation of this study was very important. Some of the methodological steps of this study are as follows: (i) Literature review has been done; (ii) Data of rainfall (2001-2018) and water level (2002-2018) has been collected; (iii) An appropriate analysis has been done on the basis of collected information and data from secondary sources that may help to assess the rainfall variability and water extent in the study area; (iv) Monthly average rainfall $(\mathrm{mm})$ data records of Sylhet division, Sunamganj district and Tahirpur Upazila of Tanguar haor has been analyzed form year 2001 to 2018; (v) Annual water level anomaly $(\mathrm{mm})$ data of Sunamganj district has been analyzed and Monthly average water level (m) data records of Surma river at Tanguar haor has been analyzed from year 2002 to 2018; (vi) Analysis of rainfall variability and water extent has been done to find out its effect on ecological settings of the study area and (vii) Finally some strategies have been follow up for the management of flash flood in Tanguar haor basin area that will help to take both proactive and reactive activities to minimize the effects of flash flood.

This study is mainly based on secondary sources of data and information. The secondary sources of data were as follows: Climate Change Knowledge Portal, International Union for Conservation of Nature (IUCN) project and from different report, research articles, books, journal papers and many more related to it.

\section{RESULTS AND DISCUSSION:}

\section{Rainfall Variabilityand Water Level in Tanguar Haor}

Climate change parameter (rainfall, water level) data in Tanguar haor - From Climate Change Knowledge Portal and IUCN, the collected data on rainfall (2001-2018), and water level (2002-2018) for this study are as follows and shown in Table 1.

Table 1: Climate change parameter data with periods of records in Tanguar haor area.

\begin{tabular}{|c|l|c|}
\hline $\begin{array}{c}\text { Data } \\
\text { type }\end{array}$ & $\begin{array}{l}\text { District or River (water } \\
\text { level and discharge) }\end{array}$ & Period \\
\hline Rainfall & $\begin{array}{l}\text { Sylhet, Sunamganj and } \\
\text { Tahirpur }\end{array}$ & $2001-2018$ \\
\hline $\begin{array}{l}\text { Water } \\
\text { Level }\end{array}$ & $\begin{array}{l}\text { Sunamganj and Surma } \\
\text { river }\end{array}$ & $2002-2018$ \\
\hline
\end{tabular}

\section{Rainfall Variability in Tanguar Haor}

Historical average rainfall records of Sylhet (2001-2018) - Tanguar haor is located in Sunamganj district of Sylhet division. Historical average rainfall data of Sylhet (2001-2018) has been shown in Fig 1.

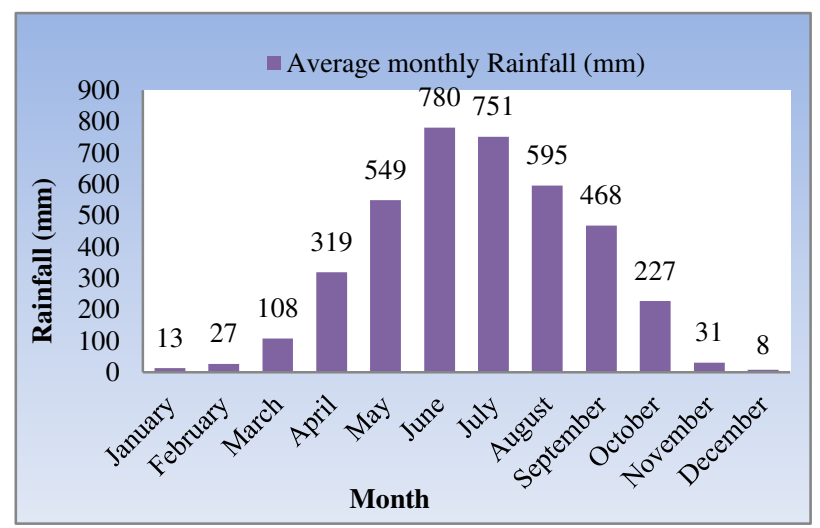

Fig 1: Historical monthly average rainfall $(\mathrm{mm})$ records of Sylhet, 2001-2018. (Source: Climate Change Knowledge Portal, 2019).

Historical data shows the Sylhet division monthly average rainfall from year 2001 to 2018. In the month of January average rainfall was $13 \mathrm{~mm}$, February $(27 \mathrm{~mm})$, March (108 mm), April (319 $\mathrm{mm})$, May $(549 \mathrm{~mm})$, June $(780 \mathrm{~mm})$, July (751 $\mathrm{mm})$, August $(595 \mathrm{~mm})$, September (468 mm), October $(227 \mathrm{~mm})$, November $(31 \mathrm{~mm})$ and in the month of December the average rainfall was $8 \mathrm{~mm}$. Fig 1 shows that Sylhet division experiences low rainfall in the month of November to February, medium rainfall in the month of March to May, High rainfall in April to September and sometimes extends in October. Highest rainfall recorded in the month of June and lowest rainfall recorded in the month of December. 
Monthly average rainfall records of Sunamganj (2001-2018) - Because of its location in the tropical monsoon region, the quantity of rainfall is very high in Sunamganj. In the early portion of the premonsoon season, a contracted zone of air mass incoherence lies over the country that sometimes flows from the southwestern part to the northeastern part (IUCN, 2014). When season headways, this discontinuity deteriorates and departures toward northwest and with draws with the end of the season whilst makes spaces for the beginning of the summer monsoon. Rainy season that overlaps with the summer monsoon is branded by southerly or southwesterly winds with very high humidity, high rainfall and extended repeated days of rainfall that separated by small time of dry days (Climate Change Knowledge Portal and Bangladesh Meteorological Department). Monthly average rainfall of Sunamganj district from year 2001 to 2018 is shown in Fig 2.

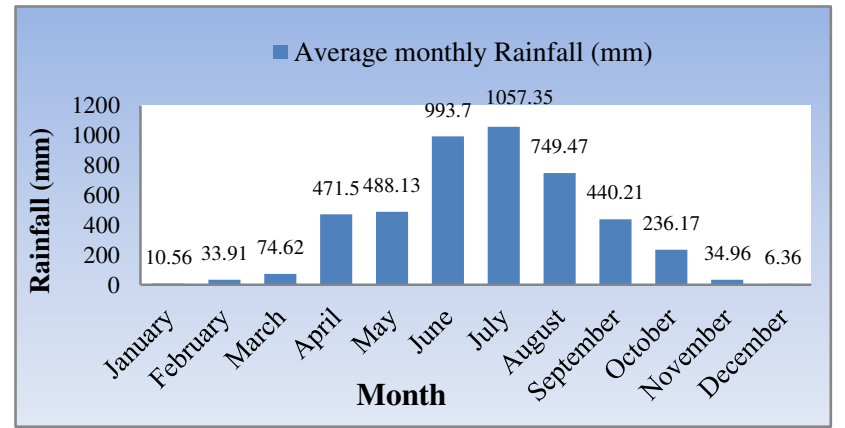

Fig 2: Monthly average rainfall ( $\mathrm{mm}$ ) of Sunamganj, 2001-2018. (Source: Climate Change Knowledge Portal, 2019).

Fig 2 shows that monthly average rainfall from year 2001 to 2018 of Sunamganj district. In the month of January average rainfall was $10.56 \mathrm{~mm}$, February (33.91 mm), March (74.62 mm), April (471.5 mm), May $(488.13 \mathrm{~mm})$, June $(993.7 \mathrm{~mm})$, July (1057.35 $\mathrm{mm})$, August (749.47 mm), September (440.21 mm), October $(236.17 \mathrm{~mm})$, November $(34.96 \mathrm{~mm})$ and in the month of December the average rainfall was 6.36 mm. Fig 2 shows that Sunamganj district experiences low rainfall in the month of November to February, medium rainfall in the month of March to May, High rainfall in April to September and sometimes extends in October. Highest rainfall recorded in the month of June and lowest rainfall recorded in the month of December.

Monthly average rainfall records of Tahirpur in Tanguar haor (2001-2018) - Tanguar haor of Tahirpur region is bounded by Meghalaya state of India on the north. This area generally experiences high rainfall in monsoon season but sometimes in premonsoon season. Monthly average rainfall of Tahirpur upazila from year 2001 to 2018 is shown in Fig 3.

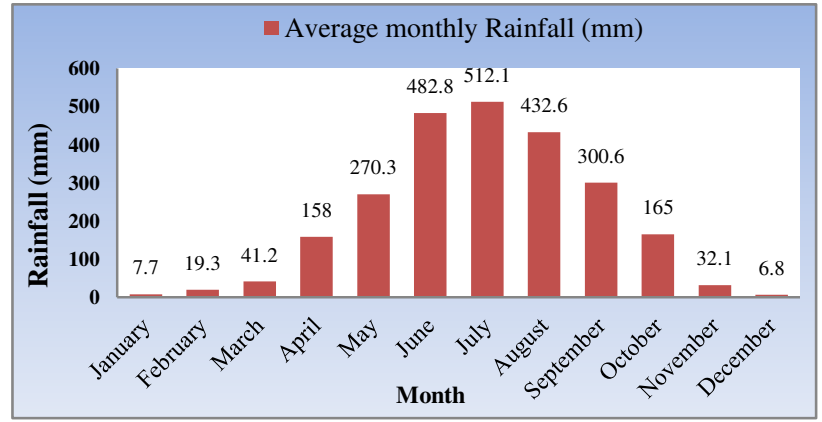

Fig 3: Monthly average rainfall $(\mathrm{mm})$ of Tahirpur, 2001-2018 (Climate Change Knowledge Portal, 2019).

Fig 3 presents the monthly average rainfall from year 2001 to 2018 of Tahirpur upazila. In the month of January average rainfall was $7.7 \mathrm{~mm}$, February (19.3 mm), March (41.2 mm), April (158 mm), May (270.3 mm), June $(482.8 \mathrm{~mm})$, July $(512.1 \mathrm{~mm})$, August (432.6 mm), September (300.6 mm), October $(165 \mathrm{~mm})$, November $(32.1 \mathrm{~mm})$ and in the month of December the average rainfall was $6.8 \mathrm{~mm}$. Fig 3 shows that Tahirpur upzila experiences low rainfall in the month of November to February, medium rainfall in the month of March to May, High rainfall in April to September and sometimes extends in October. Highest rainfall recorded in the month of June and lowest rainfall recorded in the month of December.

Water Level Flow and Extent in Sunamganj (2002-2018) - Waters in the Sunamganj district consist mainly of water from the rivers systems located south of the Sunamganj district. Water is also received from streams flowing from the hills in India at the north. During the wet seasons, water levels gradually rise as water flows from the SurmaKushiyara rivers that bounded with the district area (Rahaman et al., 2014). Due to increased rainfall and streams in Sunamganj district, the mean sea level or water level of Surma river increased and that's why this district specially haor area experiences flash flood events (Muzaffar and Ahmed, 2006). During dry season due to rainfall shortage and decrease of mean sea level of Surma river the district experiences drought situation and portable water crisis but it is less in average. Annual average sea 
water level of Sunamganj district from year 2002 to 2018 is shown in Fig 4.

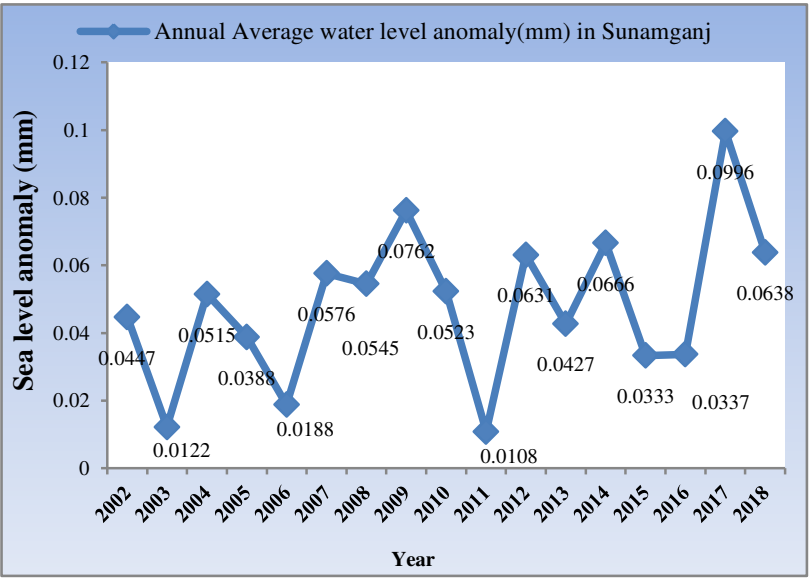

Fig 4: Annual average water level anomaly $(\mathrm{mm})$ of Sunamganj district, 2002-2018. (Source: Climate Change Knowledge Portal, 2019).

Fig 4 presents the annual average water level anomaly (mm) from year 2002 to 2018 of Sunamganj district. In the year of 2002 annual average water level anomaly was $0.0447 \mathrm{~mm}, 2003$ $(0.0122 \mathrm{~mm}), 2004(0.0515 \mathrm{~mm}), 2005(0.0388$ $\mathrm{mm}), 2006(0.0188 \mathrm{~mm}), 2007(0.0567 \mathrm{~mm}), 2008$ $(0.0545 \mathrm{~mm}), 2009(0.0762 \mathrm{~mm}), 2010(0.0523$ $\mathrm{mm}), 2011(0.0108 \mathrm{~mm}), 2012(0.0631 \mathrm{~mm}), 2013$ $(0.0427 \mathrm{~mm}), 2014(0.0666 \mathrm{~mm}), 2015$ (0.0333 $\mathrm{mm}), 2016(0.0337 \mathrm{~mm}), 2017(0.0996 \mathrm{~mm})$ and in the year of 2018 the annual average water level anomaly was $0.0638 \mathrm{~mm}$. Fig 4 shows that Sunamganj district experiences lowest annual average water level anomaly $(\mathrm{mm})$ in the year of 2011 and highest annual average water level anomaly (mm) in the year of 2017 .

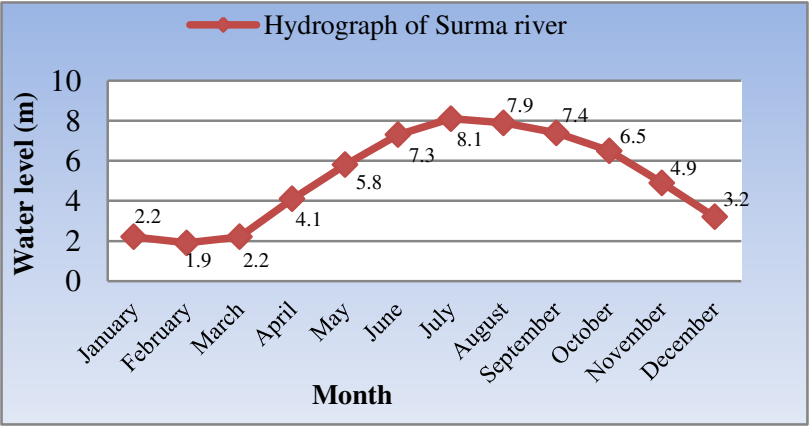

Fig 5: Monthly average water level (m) of Surma river, 2002-2018 (IUCN, 2018).

Monthly average water level of Surma river in Tanguar haor (2002-2018) - Waters in the Tanguar haor consist mainly of water from the Surma rivers system that bounded the Tanguar haor in Sunamganj district. Monthly average water level extent of
Surma River at Tanguar haor from year 2002 to 2018 is shown in Fig 5. Fig 5 presents the monthly average water level extent of Surma river at Tanguar haor from year 2002 to 2018. In the month of January average water level was $2.2 \mathrm{~m}$, February $(1.1 \mathrm{~m})$, March (2.2 m), April (4.1 m), May (5.1 m), June $(7.3 \mathrm{~m})$, July $(8.1 \mathrm{~m})$, August $(7.9 \mathrm{~m})$, September (7.4 m), October (6.5 m), November (4.9 $\mathrm{m})$ and in the month of December the average water level of Surma river was $6.8 \mathrm{~m}$. From Fig 5, highest monthly average water level of Surma river at Tanguar haor records in the month of July and lowest average water level of Surma river records in the month of February.

This study found that the pattern and quality of water flowing through the wetlands have been altered substantially due to changing flow pattern in feeder river such as Surma river as well as various water management and infrastructure development schemes in Tanguar haor areas. During the wet seasons, water levels within the haor area gradually rise as water flows from the Surma rivers into the haor. In dry season, water level recedes as reversal of flow takes place with the falling stage in rivers as well as evaporation exceeds rainfall. It is observed that July-September period represents high flow season and November-April period low flow season. Due to heavy rainfall the study area usually experiences flood in monsoon season but, sometimes during pre-monsoon season heavy rainfall and streams from mountains area raises the water level of study area bounded rivers that flows to the haor basins and causes flash flood in the Tanguar haor of Sunamganj.

\section{Effect of Rainfall Variability and Water Extent in} Tanguar Haor Area - From the above discussion it is clear that Tanguar Haor region is a high rainfall area. Approximately $80 \%$ of annual total rainfall occurs in the period of July to September. During pre-monsoon season of March to May Tanguar haor area experiences flash flood due to high rainfall, water level extent and streams form mountain area. During the wet seasons, water levels within the haor area gradually rise as water flows from the rivers into the haor. But in dry season water level recedes as reversal of flow takes place with the falling stage in rivers as well as evaporation exceeds rainfall. This time the haor area experiences drought condition and 
potable water crisis but less in average and its effects are less than flash flood events.

Aprimary survey has been conducted by Rahaman et al., (2014) titled as "A study on Climate Change Impact on the Livelihoods of the people in Tanguar Haor, Bangladesh" is assessed the respondents perception levels of different climate change induced events in Tanguar haor that are as follows: flash flood (80\%), heavy rainfall (87\%), cyclone (40\%), river erosion (63\%), drought (44\%), potable water crises (15\%). Rahaman et al., (2014) reveal that the most recurrent disastrous events in Tanguar haor is flash flood and it's occur as a result of variability in rainfall pattern and high water extent in the study area. The occurrence of high rainfall over the study area and the level of perception nearby heavy rainfall is approximately $87 \%$ which is moderately higher than other disastrous events such as river bank erosion, cyclone, potable water crises etc. Heavy rainfall forces $50 \%$ of the respondents to change their crop calendar, $18 \%$ of the respondents to switch the jobs, $12 \%$ of the respondents to face the problem of home damages and damage communication. Drought is not a very common problem in this area. But in November-February the water dried out sometimes drought happens and the perception level is $44 \%$. The climate effects result not only from gradual changes in temperature and sea level rise, but also, in particular, from increased climate variability and extremes, including more intense floods, droughts, and storms. According to Rahaman et al., (2014) floods cause $43 \%$ respondents to migrate and $35 \%$ population to switch jobs. Due to flood, $77 \%$ of the respondents are affected by property loss, disease and shortage of drinking water. Climate induced events on Tanguar haor area are shown in Fig 6.

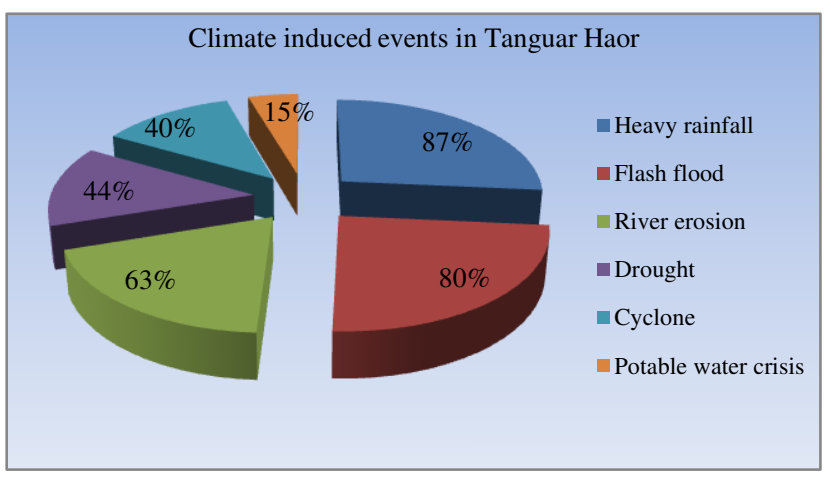

Fig 6: Climate induced events in Tanguar haor (Source: Rahaman et al., 2014).
This study found the highest variability in rainfall and water extent during the pre-monsoon season when flash flood normally occurs. The effect of rainfall variability and water extent in Tanguar haor causes the flash flood more frequently than other climatic events.

\section{Chronological events of flash flood and its effects}

Flooding in Bangladesh is a normal and frequently recurrent phenomenon. Flash flood is the most common types of floods in Bangladesh. Flash flood arises from the overflow of the bank of hilly rivers, rain causes floods due to poor drainage systems, sometimes monsoon floods in the flood plains of major adjacent rivers and coastal floods occurs from following storm surge due to variability in rainfall pattern and due to very high water extent. Haor basin area of Bangladesh affected mostly by the events of flash flood than the other region because of low lying land covered in the haor basin area. Chronological events of flood and its effects are shown in Table 2.

Table 2: Chronological events of flood in Bangladesh and its effects.

\begin{tabular}{|c|c|c|c|}
\hline Year & $\begin{array}{c}\text { Affected } \\
\text { People }\end{array}$ & $\begin{array}{c}\text { People } \\
\text { Killed }\end{array}$ & $\begin{array}{c}\text { Economic } \\
\text { damage } \\
\text { (US\$×1000) }\end{array}$ \\
\hline 2017 & $9,536,905$ & 299 & $3,450,000$ \\
\hline 2016 & $3,20,000$ & 42 & $2,25,000$ \\
\hline 2015 & $2,00,000$ & 19 & - \\
\hline 2007 & $13,771,380$ & 1110 & - \\
\hline 2004 & $36,000,000$ & - & $2,200,000$ \\
\hline 1998 & $15,000,050$ & 1050 & $4,30,000$ \\
\hline 1995 & $12,656,006$ & - & - \\
\hline 1993 & $11,469,537$ & - & - \\
\hline 1988 & $45,000,000$ & 2379 & $2,137,000$ \\
\hline 1987 & $29,700,000$ & 2055 & 727,500 \\
\hline 1984 & $30,000,000$ & 1200 & - \\
\hline
\end{tabular}

(Source: Tanvir, 2015; FFWC, 2018; Hossain et al., 2019).

Recent event of flash flood and its effects - The effect of floods has both negative and positive consequences that vary depending on location, duration, depth and speed, as well as the vulnerability of the affected natural and constructed environment. Heavy rain falls and water from the upstream Meghalaya hills in India have headed to 
the inundation of vast areas of croplands of haor basins and also the low-lying areas of the northeast parts of Bangladesh. According to the national dailies of the Daily Star, Daily Janakantha and Samakal April 08, 12 and 13, 2017; flood affected six districts (Sylhet, Moulavibazar, Sunamganj, Habiganj, Netrokona and Kishoreganj) in the north east part of Bangladesh. Rising water run-off and breaded polder in many places and inundated the vast areas of croplands of the country. It destroyed nearly-ready-for-harvesting boro rice in about 160,170 hectors areas (DAE, 2017). Detailed effect scenario of flash flood, 2017 in Bangladesh is shown below in Table 3.

Table 3: Effect of flash flood in Bangladesh, 2017.

\begin{tabular}{|c|c|c|c|}
\hline \multicolumn{2}{|c|}{ Location } & \multirow{2}{*}{$\begin{array}{c}\text { Impact on } \\
\text { Agriculture (Hec.) }\end{array}$} & \multirow[t]{2}{*}{ Sources } \\
\hline District & Upazila (No) & & \\
\hline Netrokona & 09 & 18,880 & The Daily Star report, 19 April, 2017 \\
\hline Kishoreganj & 06 & 23,300 & $\begin{array}{l}\text { Department of Agricultural Extension (DAE), } \\
\text { Kishoreganj (Dhakatribune.com); April 08, } 2017\end{array}$ \\
\hline Habiganj & - & 13,500 & Agricultural Authorities of Habiganj \\
\hline Sylhet & 13 & - & The Daily Star report, 19 April, 2017 \\
\hline Moulavibazar & - & 12,800 & DDM report; April 01, 2017 \\
\hline Sunamganj & 11 & 91,690 & $\begin{array}{l}\text { The Daily Star report, } 19 \text { April, 2017, Department of } \\
\text { Agricultural Extension (DAE), Sunamganj; April 04, } \\
2017\end{array}$ \\
\hline \multicolumn{2}{|c|}{ Total } & 160,170 & \\
\hline
\end{tabular}

Table 4: Effect of flash flood in Tanguar haor, 2017.

\begin{tabular}{|c|c|c|c|c|c|}
\hline $\begin{array}{c}\text { Affected area } \\
\text { under } \\
\text { cultivation } \\
\text { (hec.) }\end{array}$ & $\begin{array}{c}\text { Damage of } \\
\text { standing crops in } \\
\text { boro field (hec.) }\end{array}$ & $\begin{array}{c}\text { Migration of } \\
\text { population } \\
(\boldsymbol{\%})\end{array}$ & $\begin{array}{c}\text { Property loss of } \\
\text { population (\%) }\end{array}$ & $\begin{array}{c}\text { Shortage of } \\
\text { drinking } \\
\text { water (\%) }\end{array}$ & $\begin{array}{c}\text { Population affected } \\
\text { by disease (\%) }\end{array}$ \\
\hline 30,100 & 18,200 & 33 & 65 & 48 & 10 \\
\hline
\end{tabular}

(Source: The daily Star report; 08 and 19 April, 2017 and Nirapad, 2017)

Table 3 shows that Sunamganj district has been affected most extensively due to flash flood in 2017. According to Department of Agricultural Extension (DAE), 2017 total area affected (under boro cultivation) in Dharmapasha and Tahirpur upazila was 50,200 hec and damage of standing crops in boro field was 26,220 hec. Main problem associated with the Tanguar haor was heavy rainfall and extent water logging that causes frequent flash flood. Effect of flash flood in Tanguar haor is shown in Table 4.

Extent Water Level and its Influences in Ecological Settings in Tanguar Haor - Tanguar haor experiences a large variation in water level. Seasonal variation in rainfall, temperature, evaporation, upstream water flow, groundwater table reflect in water fluctuation into the haor area $(\mathrm{GoB}$, 2004). During monsoon, almost all of the areas go under water. During pre-monsoon season the haor area experienced sudden rising of water as result of flash flood. In post monsoon season the haor area experienced water crisis but this scenario do not seen every season and it is less in average. Variation of water level in Tanguar haor has greater influences in its ecological settings (IUCN, 2014), as Tanguar haor is a large water logged area between banks of large rivers of Surma-Kushiyara.

Water influences on flora and fauna - Floral composition in Tanguar haor are; submerged plants, free floating plants, rooted floating plants, sedges and meaclows, reed swamp, fresh water swamp forest, crop field vegetation and homestead vegetation (Chakraborty, 2005; Chowdhury, 2004 and IUCN, 2002). When there is high water in the haor area then increases the growth of floral composition. But sometimes high flow of water washes away the floral composition one place to another. This causes the scarcity of floral composition in the respected area. 
In low water season the floral composition going to dries up that causes the diversity of floral composition. Faunal compositions of Tanguar haor are fish species, amphibians, reptiles, birds and mammals (BLI, 2012). High water level in the Tanguar haor sometimes causes the increases of faunal composition. Living places of faunal composition are changes that cause the migration of faunal species.

\section{Water influences on agricultural crop production}

- Agricultural crop production is the main livelihood activities of the people of Tanguar haor area. Boro crop are mainly cultivated here. During monsoon season high water level causes the crop production damaged. All of the cultivated land goes under the water and crops are destroyed. During pre-monsoon season sudden flash flood destroy the crops of the haor area. In post monsoon season means the drought season causes the water scarcity but it is less in amount, it causes the crop production hampered.

Water Influences on fisheries - The fisheries resources of Tanguar Haor is very amusing and has a high importance in terms of fish production, fish habitat, breeding support, national economy and livelihood support. The haor is very important in terms of fish species diversity. Most common fish species found in Tanguar haor area according to percentage basis are Rui, Chingri, Puti, Gonia, Tengra, Kalbaush, Shol, Gajar and Taki, Chanda, Meni, Catla, Grass carp, Baul and some other species (Nuruzzaman and Khan, 1997). High water level causes the rapid growth of fish species. Due to flood there is abundant of food in water for the fishes. During high water season and after flood haor area experiences the availability of fishes. Water pollution and toxic measures of water causes the deaths of fish species. But water logging results the water pollution that causes the destruction and deaths of fish species.

Water influences on wildlife habitat - Several wild life habitats have found in the haor area and most of them are migratory and resident birds. Among them both are aquatic and terrestrial (IUCN, 2007). Migratory bird comes in Bangladesh mainly in winter season. Sometimes from different parts of the country migratory birds moved in Tanguar hoar for their nesting and fooding. When haor area experienced high level of water, that may causes both in beneficial and non-beneficial condition for the migratory bird. Availability of water essential for their floating and nesting but it causes the lack of food for them. Sometimes flood condition created uncomfortable situation for the wildlife habitat to live. Water pollution and toxic measures of water causes the deaths of wildlife habitat.

Water influences on population and livelihood activities - Livelihood activities of people live in Tanguar haor based on the resources and opportunities of haor area. Livelihood activities of this area are related to agricultural crop production, fishing, and homestead vegetation and on animal farming activities (Rahaman et al., 2014). Due to high water level at the Tanguar haor area the living people deprived from their livelihood activities. Land goes under water that causes the crop cultivation and homestead vegetation activities are badly hampered (Thikader, 2004). But the fishing activities increased. Flash flood causes sudden disruption to the livelihood activities and haor area people become helpless. Different diseases have broken out during the flood time. Sometimes water pollution causes the spread of several waterborne diseases that create more vulnerability. People lost their livelihood activities due to flood and became migrated to another area that makes their lifestyle more difficult to live well.

Flash Flood Management Strategies in Tanguar Haor - Tanguar haor in Bangladesh is an important source of livelihood for a large number of the rural poor community. During winter, cultivated lands of the haor produce paddy with minimum efforts while during the monsoon the same become breeding places for open water fishery hosting a wide range of water biodiversity. But early flash floods often wash away standing crops and people lose their production. Here some strategies for the management of flash flood in Tanguar haor area has been followed up that modified and adopted from Farid, 2017; Elahi, 1988, Anwar, 2007; Haque et al., 2017; IUCN, 2007; Nishat et al., 1993 and Hossain, 2013.

Short term actions - Some short term actions that may be found useful in strengthening protection practices during flash floods are as follows: (i) immediate actions are needed by respective authorities to make and complete the repair works of earthen embankments or dykes in vulnerable spots of haor regions in conjunction and cooperation with 
community members and local government bodies; (ii) appropriate allocation of fund, quick release of fund and effective monitoring management under effective supervision should be ensured at different levels; (iii) role of local government bodies and community members at different stages of the work and flash flood situations needs to be emphasized, supported, encouraged and ensured by the authorities.

Long term steps - Some long-term suggestions that may be found useful in strengthening protection practices during flash floods are as follows: (i) earthen embankment is an economically smart intervention for protecting flash flood events. However, limitations such as difficulties of physical works and weak management set-up for operation, maintenance and protection, including lack of engagement of community people in the process needs to be addressed effectively for involving all key actors; (ii) effect minimizing strategies such as the practices of cropping patterns, which minimizes the exposure to losses and setting up of nonagricultural income-generating activities need to be promoted. Crop type and pattern should be selected according to susceptibility of flood. Effort should be taken by concerned agencies to find out new variety of crops resilient in combating flash floods; (iii) any livelihood initiative in the haor areas need to take into consideration the flood history so that the initiative does not give in, rather yield some amount of benefit to the targeted and affected people. Involvement of the community and enlisting their inputs in the any kind of program design and relevant issues affecting their livelihood will make the intervention process more effective, easier and impact bearing; (iv) mainstreaming disaster risk reduction and climate change adaptation in the existing development works and future initiatives of different government departments and Non-Governmental Organization (NGOs) working in the areas need to redesign their development program with active participation of the most vulnerable communities to ensure that they maximize flood mitigation potential and incorporate traditional community cropping practices which can fit technically, environmentally and economically and socially; (v) well organized and coordinated effort is needed to strengthen local level planning, decision making process and allocation of resources to local government bodies; (vi) measures for forecasting flash floods should be geared up. Improvement of present forecasting system is very much needed. Flash flood related awareness raising activities need to be provided. Cross boarder steps should be explored by technical authorities in this regard; (vii) coping adaptation strategies such as migration, reconstruct houses, job switching, and changes in crop calendar, follow weather forecast and early warning system are more important for the management of flash flood in haor basin.

\section{CONCLUSION:}

Tanguar haor experiences high rainfall variability and water extent during pre-monsoon period when flash flood normally occurs. Any rotation of rainfall and water extent as a result of climate change causes flash flood in the Tanguar haor basin area. During the wet seasons, water levels within the haor area gradually rise as water flows from the rivers into the haor. The rivers in the Tanguar haor basin are flashy in nature and flash floods occur in the pre-monsoon months of March to May. This study has done an appropriate analysis of rainfall and water level of Tanguar haor based on information and data collected from secondary sources. This study founds high rainfall variability and flash flood as more frequent climatic events in this haor region. The outcome of the study may help to incorporate new concept about the ground level significance of flash flood management in haor basin area. Results from this study action may take care of all responsible authority to increase the practices of coping adaptation strategies due to high rainfall variability and water extent. It is certainly can act as a substitute to detailed and in-depth analysis at the level of concern.

\section{ACKNOWLEDGEMENT:}

Thanks to the co-author supported with proper assistance and help for data analysis and writing to conduct successful research.

\section{CONFLICTS OF INTEREST:}

The authors declare that they have no potential conflicts with respect to the research work.

\section{REFERENCES:}

1) Anwar, C. H. (2007). The state of Community Based Sustainable Management of Tanguar Haor, What measures are to be taken? P. 142. 
2) Ashfaq, H. (2012). Sunamganj DistrictDetail: National Encyclopedia of Bangladesh (Second. ed.), Asiatic Society of Bangladesh.

3) Bangladesh haor and Wetland Development Board (BHWDB), (2012). Haor Master Plan, Dhaka, Bangladesh.

4) Bevanger, K., Datta, A. K., Eid, A. T. and Shirin, M. (2001). Tanguar Haor Wetland Biodiversity Conservation Project, NINA NIKU Project Report-16. p. 1-37. https://www.nina.no/archive/nina/PppBasePd f/prosjektark/projectReport/016.pdf

5) Bird Life International (BLI), (2012). Important Bird Areas factsheet: Tanguar Haor and Panabeel. Available at http://www.birdlife.org

6) Chakraborty, T. R. (2005). Fish and wildlife of the Chanda Beel area, IUCN Bangladesh Country Office, Dhaka, Bangladesh.

7) Chowdhury, M. (2004). Wetland Biodiversity: a case study of Tanguar Haor in Bangladesh state of Biodiversity, Forum of Environment Journalist of Bangladesh. p. 5166.

8) Climate Change Knowledge Portal, (2019). Monthly average rainfall data of Sylhet division, Sunamganj district, Tahirpur upazila, Annual average water level data of Sunamganj district and Monthly average water level data of Surma river.

9) Department of Agriculture Extension (DAE), (2017).Detailed impact of flash flood in Sunamganj district, April 04, 2017.

10) Elahi, K. M. (1988). Socio Economic Impact of Flood and Coexistence with Flood, Bangladesh: Geography, Environment and Development. Bangladesh National Geographical Association, Dhaka. p. 55-67.

11) Farid, H. A. (2017). Flash flood management strategies in Haor basin area of Bangladesh. The financial express, Dhaka.

12) FFWC, (2018). Chronological events of flood in Bangladesh and its effects.

13) GoB, (2004). Haor Wetland, Biodiversity Conservation Project. Ministry of Environment and Forests. Government of the People's Republic of Bangladesh.

14) Haque, M. M. (2017). A critical assessment of knowledge quality for climate adaptation in Sylhet Division, Bangladesh. Journal of Climate Risk Management, 16, 43-58. http://dx.doi.org/10.1016/j.crm.2016.12.002

15) Hossain, B., Sohel, M. S. and Ryakitimbo, C. M. (2019). Climate change induced extreme flood disaster in Bangladesh: Implications on people's livelihoods in the Char Village and their coping mechanisms. Progress in Disaster Science, 6, 100079. http://dx.doi.org/10.1016/j.pdisas.2020.100079

16) Hossain, M. S. (2013). Flood manages and risk assessment model in the haor basin of Bangladesh. Bangladesh University of Engineering and Technology, Dhaka.

17) IUCN, (2002). Bio-ecological zones of Bangladesh, International Union for Conservation of Nature and Natural Resources, Bangladesh, p. 31.

18) IUCN, (2007). Tanguar Haor, Bangladesh. Retrieved, 2007-11-23.

19) IUCN, (2014). International Union for Conservation of Nature, IUCN, Bangladesh Country Office.

20) IUCN, (2018). Monthly average water level in Surma River, Retrieved, 2019.

21) Klein, R. J. T. (1998). Towards better understanding, assessment and funding of climate adaptation, Climate Change, p.15-19.

22) Munasinghe, M. (2000). Development, equity and sustainability (DES) in the context of climate change. IPCC Expert Meeting in Colombo, 1999.

23) Muzaffar, S. B. and Ahmed, F. A. (2006). The effects of the flood cycle on the diversity and composition of the phytoplankton community of a seasonally flooded Ramsar wetland in Bangladesh, 15(2), p. 81-93.

24) Nishat, A., Hussain, Z. and Karim, M. K. R. A. (1993). Freshwater Wetlands in Bangladesh: Status and Issues, in Freshwater Wetlands in Bangladesh: Issues and Approaches for Management, IUCN-The World Conservation Union, Dhaka.

25) Nuruzzaman, M. and Khan, S. (1997). NCS Report on Fisheries: Towards Sustainable Development: The National Conservation Strategy of Bangladesh, Fisheries Resource Survey System of Department of Fisheries. P. 24-27. 
26) Rahman, M. M., Sajib, K. I. and Alam, I. (2014). A study on Climate Change Impact on the Livelihoods of the people in Tanguar Haor, Department of Civil Engineering. University of Asia Pacific, Dhaka.

27) Rashid, H. (1991). Geography of Bangladesh. University Press Limited, Dhaka.

28) Reports of DDM, DAE April 01, 04 and 05, 2017, national dailies (the Daily Star, Prothom Alo, Dhaka Tribune, Daily Janakantha, Samakal, Nirapad on April 08, 12, 13 and 19, 2017. Flash Flood Situation of Bangladesh, 2017.

29) Saju JA, Rubel SNR, Rahman MM, Nayan SB, and Bagchi R. (2020). Effectiveness of manual bar screen in separating solid waste from municipal sewers of Khulna city, Aust. J. Eng. Innov. Technol., 2(3), 31-41. https://doi.org/10.34104/ajeit.020.031041

30) Sara, N., Murshed, S. B., Islam, A. K. M. S. and Bhaskaran, B. (2013). Change of Future Climate Extremes for the Haor Basin Area of Bangladesh. $4^{\text {th }}$ International Conference on Water \& Flood Management. p. 545.

31) Siddiqi, S. (2012). Cultural Survey Report of Sunamganj District. $2^{\text {nd }}$ Ed. National Encyclopedia of Bangladesh.

32) Tanvir, H. D. (2015). Societal impacts and vulnerability to floods in Bangladesh and Nepal. Journal of Weather and Climate Extremes. 7, p. 36-42.

https://doi.org/10.1016/j.wace.2014.11.001

33) Thikader, B. (2004). Baira: new scope of cultivation. Environment Newsletter, 8, p.1-2.

Citation: Bagchi R, Miah MA, Hazra P, Hasan R, Mondal HS, and Paul SK. (2020). Exploring the effect of rainfall variability and water extent in tanguar haor, Sunamganj, Aust. J. Eng. Innov. Technol., 2(4), 66-76. https://doi.org/10.34104/ajeit.020.066076 (c) 